\title{
Osteomalacia and osteoporosis: evaluation of a diagnostic index
}

\author{
MJ McKENNA, ${ }^{*}$ R FREANEY, OM CASEY, RP TOWERS, FP MULDOWNEY \\ From the Department of Metabolism and Renal Disease and Department of Pathology, St Vincent's Hospital, \\ Dublin 4, and, Department of Medicine, University College Dublin
}

SUMMARY Data from a retrospective study in 41 patients is used to suggest an index of bone disease. This is designed as a means of collating available results, clarifying the significance of each in diagnosing either osteomalacia or osteoporosis, and reducing the significance of a single abnormal finding - for example, a raised alkaline phosphatase activity or low serum 25 hydroxy vitamin $\mathrm{D}$, when the overall index score is low. Index scores above $35 \%$ would be diagnostic of osteomalacia; scores below $15 \%$ if associated with collapsed vertebrae suggest osteoporosis. Scores between $15 \%$ and $35 \%$ would indicate the need for a bone biopsy to discriminate between osteoporosis and osteomalacia.

Osteoporosis and osteomalacia are common forms of metabolic bone disease. They share certain features in common-namely, bone pain, decreased bone radio-density, and bone fractures. ${ }^{1}$ Differential diagnosis is often difficult without recourse to bone biopsy. Histological demonstration of excess osteoid with a mineralisation defect is diagnostic of osteomalacia. ${ }^{2}$ The finding of normal bone composition (and decreased bone volume, where measured). contributes to a diagnosis of osteoporosis, which is a diagnosis made by the exclusion of other forms of metabolic bone disease. ${ }^{3}$

Morgan $^{4}$ suggested that osteomalacia could be diagnosed on the basis of biochemical and radiological abnormalities and clinical features and felt that bone biopsy was rarely necessary. In a retrospective study of 41 subjects we are examining this question, and for that reason we have designed and applied an index of metabolic bone disease (Table 1) as a means of collating and evaluating data from investigative procedures in such patients. The diagnostic procedures are each assigned a numerical value or score and the resultant score sheet is the index and is analagous to indices used in the diagnosis of thyroid disorders ${ }^{5}$ or in the assessment of disease status in cystic fibrosis. ${ }^{6}$

The reduction of the need for an invasive test such as a bone biopsy is desirable and would be possible if

\footnotetext{
${ }^{*}$ Research Fellow to Our Lady's Manor, Dalkey, Dublin.
}

Accepted for publication 30 September 1982 alternative non-invasive procedures could be shown to yield results upon which diagnosis could be firmly made. In this communication we hope to demonstrate the capacity of the index to separate those with

Table 1 Osteomalacialosteoporosis discriminant index

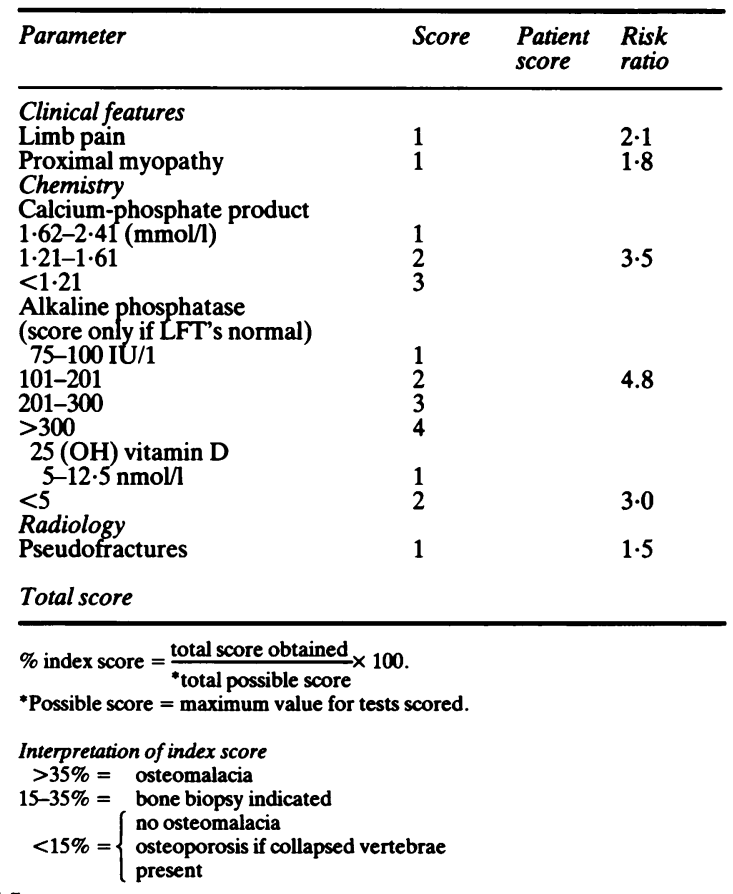


osteomalacia from those with osteoporosis, to demonstrate when a biopsy is indicated, and in addition to evaluate the capacity of any single parameter to forecast the final diagnosis. Such an approach would be particularly helpful in the assessment of elderly subjects since osteoporosis and osteomalacia are common disorders in the elderly, and invasive procedures are undesirable.

The osteoid volume measured in the bone biopsy samples is the parameter against which the index is assessed. However once a bone biopsy has been performed (as in this retrospective study) additional or alternative information such as the number of lamellae, the bone ash content, and the pathologist's subjective evaluation may also be obtained. In this communication the relative diagnostic importance of these investigations compared to the osteoid volume is noted.

\section{Material and methods}

PATIENTS STUdiED

The data were obtained from 41 subjects previously diagnosed as having metabolic bone disease. All subjects studied had normal renal function, and none had radiological evidence of Paget's disease. They were divided into two groups. Tables 2 and 3 show clinical, biochemical, histological features, and diagnoses. No patient had primary hyperparathyroidism or hyperthyroidism.

Group 1 consisted of 26 subjects ( 20 women, 6 men: mean age $52 \mathrm{yr}$, range 17 to $74 \mathrm{yr}$ ) with osteomalacia diagnosed on the basis of osteoid volume greater than $2.4 \%$ on quantitative bone histology, as defined in methods section (normal range $\pm 2 S D=0-2 \cdot 4 \%$ ). Group 2 consisted of 15 subjects (11 women, 4 men: mean age $57 \mathrm{yr}$, range 29 to $69 \mathrm{yr}$ ) with osteoporosis

Table 2 Biochemical and histological findings in osteomalacia (group 1) and osteoporosis (group 2)

\begin{tabular}{|c|c|c|c|c|c|c|c|}
\hline Subjects & $\begin{array}{l}\text { Osteoid } \\
\text { volume (\%) }\end{array}$ & $\begin{array}{l}\text { Serum } \\
\text { calcium-phosphate } \\
\text { product (mmolll) }\end{array}$ & $\begin{array}{l}\text { Alkaline } \\
\text { phosphatase } \\
\text { (IUIl) }\end{array}$ & $\underset{(\text { nmolll) }}{25(\mathrm{OH})}$ vit D & $\begin{array}{l}\text { Ash content } \\
(\%)\end{array}$ & $\begin{array}{l}\text { Maximum } \\
\text { number of } \\
\text { lamellae }\end{array}$ & $\begin{array}{l}\text { Pathologist's } \\
\text { report of } \\
\text { biopsy }\end{array}$ \\
\hline $\begin{array}{l}\text { Group 1 } \\
\text { MB } \\
\text { MC } \\
\text { JC } \\
\text { JC } \\
\text { MC } \\
\text { BD } \\
\text { ED } \\
\text { AD } \\
\text { MD } \\
\text { RF } \\
\text { BH } \\
\text { AH } \\
\text { MJ } \\
\text { EK } \\
\text { JMcC } \\
\text { MMcG } \\
\text { IM } \\
\text { JM } \\
\text { AN } \\
\text { MN } \\
\text { MP } \\
\text { ER } \\
\text { HS } \\
\text { ES } \\
\text { KS } \\
\text { BW }\end{array}$ & $\begin{array}{r}7 \cdot 6 \\
35 \cdot 5 \\
25 \cdot 7 \\
41 \cdot 6 \\
7 \cdot 3 \\
2 \cdot 8 \\
23 \cdot 1 \\
22.9 \\
3 \cdot 1 \\
20 \cdot 4 \\
4 \cdot 7 \\
19 \cdot 4 \\
3 \cdot 8 \\
30 \cdot 3 \\
11 \cdot 5 \\
27 \cdot 2 \\
48 \cdot 4 \\
4 \cdot 8 \\
21 \cdot 6 \\
19 \cdot 2 \\
21 \cdot 4 \\
6 \cdot 1 \\
27.4 \\
3.3 \\
13 \cdot 5 \\
8.9\end{array}$ & $\begin{array}{l}1.76 \\
2.27 \\
1.86 \\
1.05 \\
1.76 \\
2.37 \\
1.81 \\
2.03 \\
3.16 \\
1.78 \\
0 \cdot 86 \\
1 \cdot 20 \\
1.36 \\
3.25 \\
2.54 \\
1.54 \\
1.07 \\
2.42 \\
1.82 \\
1.16 \\
1.25 \\
1.56 \\
1.48 \\
2.38 \\
1.15 \\
2.28\end{array}$ & $\begin{array}{r}474 \\
149 \\
190 \\
428 \\
43 \\
119 \\
167 \\
434 \\
156 \\
236 \\
190 \\
86 \\
59 \\
340 \\
142 \\
422 \\
215 \\
158 \\
110 \\
255 \\
142 \\
283 \\
103\end{array}$ & $\begin{array}{l}38 \\
<5 \\
<5 \\
<5 \\
<5 \\
<5 \\
<5 \\
9 \\
<5 \\
<5 \\
<5 \\
6 \\
<5 \\
9 \\
19 \\
<5 \\
7 \\
- \\
- \\
<5 \\
<5 \\
=5 \\
<- \\
- \\
-\end{array}$ & $\begin{array}{l}63 \\
31 \\
\\
55 \\
55 \\
44 \\
26 \\
47 \\
45 \\
30 \\
47 \\
54 \\
57 \\
46 \\
40 \\
43 \\
32 \\
50 \\
42 \\
47 \\
47 \\
54 \\
50 \\
50\end{array}$ & $\begin{array}{r}5 \\
7 \\
8 \\
10 \\
6 \\
3 \\
8 \\
9 \\
3 \\
9 \\
4 \\
7 \\
4 \\
10 \\
8 \\
10 \\
16 \\
5 \\
6 \\
9 \\
9 \\
3 \\
9 \\
6 \\
6 \\
6\end{array}$ & $\begin{array}{l}\text { Mild } \\
\text { Severe } \\
\text { Severe } \\
\text { Severe } \\
\text { Mild } \\
\text { Mild } \\
\text { Severe } \\
\text { Severe } \\
\text { Mild } \\
\text { Severe } \\
\text { Moderate } \\
\text { Moderate } \\
\text { Mild } \\
\text { Severe } \\
\text { Moderate } \\
\text { Severe } \\
\text { Severe } \\
\text { Mild } \\
\text { Severe } \\
\text { Severe } \\
\text { Severe } \\
\text { Mild } \\
\text { Severe } \\
\text { Mild } \\
\text { Moderate } \\
\text { Moderate }\end{array}$ \\
\hline $\begin{array}{l}\text { Group } 2 \\
\text { MB } \\
\text { EC } \\
\text { NC } \\
\text { PC } \\
\text { MD } \\
\text { JF } \\
\text { EH } \\
\text { MK } \\
\text { CK } \\
\text { JL } \\
\text { EMcG } \\
\text { EM } \\
\text { CM } \\
\text { TN } \\
\text { EO'T }\end{array}$ & $\begin{array}{l}1.4 \\
1.2 \\
1.9 \\
0.7 \\
1.2 \\
0.3 \\
2.1 \\
0.1 \\
1.5 \\
0.4 \\
0.7 \\
0.7 \\
1.5 \\
1.4 \\
0.4\end{array}$ & $\begin{array}{l}2.48 \\
2.51 \\
2.83 \\
3.21 \\
2.71 \\
1.92 \\
2.64 \\
2.71 \\
2.03 \\
3.08 \\
3.64 \\
2.94 \\
2.92 \\
1.77 \\
2.63\end{array}$ & $\begin{array}{r}65 \\
51 \\
46 \\
45 \\
35 \\
76 \\
57 \\
163 \\
79 \\
57 \\
48 \\
96 \\
46 \\
60 \\
123\end{array}$ & $\begin{array}{l}34 \\
22 \\
23 \\
50 \\
45 \\
19 \\
- \\
97 \\
62 \\
28 \\
34 \\
34 \\
30\end{array}$ & $\begin{array}{l}57 \\
54 \\
46 \\
46 \\
43 \\
47 \\
62 \\
60 \\
28 \\
53 \\
59 \\
46 \\
44 \\
50\end{array}$ & $\begin{array}{l}3 \\
4 \\
2 \\
4 \\
3 \\
0 \\
4 \\
1 \\
3 \\
2 \\
3 \\
2 \\
3 \\
4 \\
3\end{array}$ & $\begin{array}{l}\text { Normal } \\
\text { Mild } \\
\text { Normal } \\
\text { Normal } \\
\text { Normal } \\
\text { Normal } \\
\text { Normal } \\
\text { Mild } \\
\text { Normal } \\
\text { Normal } \\
\text { Mild } \\
\text { Normal } \\
\text { Normal } \\
\text { Mild } \\
\text { Normal }\end{array}$ \\
\hline
\end{tabular}


diagnosed on the basis of radiological changes (ie collapsed vertebrae) with normal bone histology.

\section{IN DEX}

The proposed index (Table 1) includes clinical features, serum chemistry (calcium-phosphate product, alkaline phosphatase, and serum 25 (OH) vitamin $\mathrm{D}$ ), and radiological findings. The osteoid volume measured in the bone biopsy samples is not scored in the index, as this is the parameter used in the classification of patients as osteomalacic and osteoporotic. Table 1 lists the scores awarded on the basis of the results obtained. The total number of points for the maximum number of abnormalities is 12. The points are expressed as a percentage of the total. This compensates in cases where investigations were not carried out or where results were excluded-that is, raised alkaline phosphatase in the presence of liver disease, as in those cases the maximum number of points would be reduced also. In this retrospective study the tests were weighted in an effort to produce a system, that would give the best separation between patients with osteomalacia and osteoporosis. The weighting was supported by the risk ratios (for detecting osteomalacia-Table 1). A risk ratio greater than one indicates that the probability of having disease is increased if a test result is positive. The assigned scores for all the parameters parallel the risk ratios for detecting osteomalacia.

\section{LABORATORY METHODS}

Serum calcium, inorganic phosphorus, alkaline phosphatase and $25(\mathrm{OH})$ vitamin D were measured as previously described. 7 Serum calcium correction for albumin was not routinely performed, using any of

Table 3 Clinical and radiological findings, index score and diagnosis in osteomalacia (group 1) and osteoporosis (group 2)

\begin{tabular}{|c|c|c|c|c|c|}
\hline Subjects & Bone pain & Proximal myopathy & Pseudofractures & Index score (\%) & Predisposing condition \\
\hline $\begin{array}{l}\text { Group } 1 \\
\text { MB } \\
\text { MC } \\
\text { JC } \\
\text { JC } \\
\text { MC } \\
\text { BD } \\
\text { ED } \\
\text { AD } \\
\text { MD } \\
\text { RF } \\
\text { BH } \\
\text { AH } \\
\text { MJ } \\
\text { EK } \\
\text { JMcC } \\
\text { MMcG } \\
\text { IM } \\
\text { JM } \\
\text { AN } \\
\text { MN } \\
\text { MP } \\
\text { ER } \\
\text { HS } \\
\text { ES } \\
\text { KS } \\
\text { BW }\end{array}$ & $\begin{array}{l}\text { Limb } \\
\text { Both } \\
\text { Back } \\
\text { Limb } \\
\text { Back } \\
\text { Back } \\
\text { Limb } \\
\text { Both } \\
\text { Both } \\
\text { None } \\
\text { Both } \\
\text { Limb } \\
\text { None } \\
\text { Both } \\
\text { Both } \\
\text { Limb } \\
\text { Both } \\
\text { Both } \\
\text { Both } \\
\text { None } \\
\text { None } \\
\text { Limb } \\
\text { Limb } \\
\text { Limb } \\
\text { Limb } \\
\text { None }\end{array}$ & $\begin{array}{l}\text { No } \\
\text { Yes } \\
\text { No } \\
\text { Yes } \\
\text { No } \\
\text { No } \\
\text { Yes } \\
\text { No } \\
\text { No } \\
\text { No } \\
\text { No } \\
\text { Yes } \\
\text { No } \\
\text { No } \\
\text { No } \\
\text { Yes } \\
\text { Yes } \\
\text { No } \\
\text { No } \\
\text { No } \\
\text { No } \\
\text { No } \\
\text { Yes } \\
\text { No } \\
\text { Yes } \\
\text { No }\end{array}$ & $\begin{array}{l}\text { No } \\
\text { No } \\
\text { No } \\
\text { No } \\
\text { No } \\
\text { No } \\
\text { No } \\
\text { Yes } \\
\text { No } \\
\text { Yes } \\
\text { No } \\
\text { Yes } \\
\text { No } \\
\text { No } \\
\text { No } \\
\text { Yes } \\
\text { Yes } \\
\text { No } \\
\text { No } \\
\text { Yes } \\
\text { No } \\
\text { No } \\
\text { No } \\
\text { No } \\
\text { No } \\
\text { No }\end{array}$ & $\begin{array}{l}50 \\
58 \\
42 \\
92 \\
25 \\
42 \\
58 \\
67 \\
38 \\
50 \\
75 \\
75 \\
50 \\
25 \\
8 \\
92 \\
88 \\
30 \\
60 \\
75 \\
50 \\
50 \\
75 \\
40 \\
80 \\
30\end{array}$ & $\begin{array}{l}\text { Idiopathic Fanconi syndrome } \\
\text { Renal tubular acidosis } \\
\text { Coeliac } \\
\text { Post gastrectomy } \\
\text { Post gastrectomy } \\
\text { Anti-convulsant } \\
\text { Coeliac } \\
\text { Coeliac } \\
\text { Privational vitamin D deficiency } \\
\text { Anti-convulsant } \\
\text { Post gastrectomy } \\
\text { Coeliac } \\
\text { Coeliac } \\
\text { Privational vitamin D deficiency } \\
\text { Privational vitamin D deficiency } \\
\text { Privational vitamin D deficiency } \\
\text { CAH secondary Fanconi syndrome } \\
\text { Privational vitamin D deficiency } \\
\text { Coeliac } \\
\text { Coeliac } \\
\text { Coeliac } \\
\text { Privational vitamin D deficiency } \\
\text { Ureterosigmoidostomy acidosis } \\
\text { Post gastrectomy } \\
\text { Malabsorption } \\
\text { Coeliac }\end{array}$ \\
\hline $\begin{array}{l}\text { Group } 2 \\
\text { MB } \\
\text { EC } \\
\text { NC } \\
\text { PC } \\
\text { MD } \\
\text { JF } \\
\text { EH } \\
\text { MK } \\
\text { CK } \\
\text { JL } \\
\text { EMcG } \\
\text { EM } \\
\text { CM } \\
\text { TN } \\
\text { EO'T }\end{array}$ & $\begin{array}{l}\text { Both } \\
\text { Back } \\
\text { Back } \\
\text { Back } \\
\text { Back } \\
\text { Back } \\
\text { Back } \\
\text { Back } \\
\text { Both } \\
\text { Back } \\
\text { Back } \\
\text { Back } \\
\text { Back } \\
\text { Both } \\
\text { Back }\end{array}$ & $\begin{array}{l}\text { No } \\
\text { No } \\
\text { No } \\
\text { No } \\
\text { No } \\
\text { No } \\
\text { No } \\
\text { No } \\
\text { No } \\
\text { No } \\
\text { No } \\
\text { No } \\
\text { No } \\
\text { No } \\
\text { No }\end{array}$ & $\begin{array}{l}\text { Yes } \\
\text { No } \\
\text { No } \\
\text { No } \\
\text { No } \\
\text { No } \\
\text { No } \\
\text { No } \\
\text { No } \\
\text { No } \\
\text { No } \\
\text { No } \\
\text { No } \\
\text { No } \\
\text { No }\end{array}$ & $\begin{array}{r}17 \\
0 \\
0 \\
0 \\
0 \\
17 \\
0 \\
20 \\
30 \\
0 \\
0 \\
8 \\
0 \\
17 \\
17\end{array}$ & $\begin{array}{l}\text { Post menopausal } \\
\text { Post menopausal } \\
\text { Post menopausal } \\
\text { Idiopathic } \\
\text { Post menopausal } \\
\text { Chronic steroid therapy } \\
\text { Post menopausal } \\
\text { Post menopausal } \\
\text { Post menopausal } \\
\text { Idiopathic } \\
\text { Immobilisation } \\
\text { Post menopausal } \\
\text { Post menopausal } \\
\text { Idiopathic } \\
\text { Post gastrectomy }\end{array}$ \\
\hline
\end{tabular}

Both = back and limb pain. 
the proposed correction factors. ${ }^{8}$ Full thickness bone biopsy specimens were taken from the iliac crest. ${ }^{9}$ One sample was fixed in formalin and used for histological examination. Silver staining of the bone prior to decalcification was performed. ${ }^{10}$ Osteoid area was measured by a projection method described by Towers, ${ }^{11}$ and it was expressed as a percentage of the total trabecular bone area-that is, relative osteoid volume. Normal values were established by analysis of bone from 10 subjects who died suddenly and did not have post-mortem evidence of renal, hepatic, and intestinal disease. The mean osteoid volume in this group was $0.8 \pm 0.8 \%$ (SD) which agreed well with previously reported values. ${ }^{12}{ }^{13}$ The maximum number of lamellae (bright lines) per osteoid seam seen under polarised light was also determined. ${ }^{14}$

The second specimen was scraped free from any adhering muscle attachments and allowed to dry to a constant weight at $100^{\circ} \mathrm{C}$. The dried bone was defatted with diethyl-ether-petroleum ether (1:1) mixture and the fat free dry bone ashed at $500^{\circ} \mathrm{C}$. The $\%$ ash is the ash weight/fat free dry weight $\times 100$. Normal values from our 10 subjects (mean $\pm S D=61$ $\pm 3 \%$ ) agreed well with those reported by Agna, Knowles and Alversen ${ }^{15}$ from 16 subjects ranging from 23-62 yr.

\section{STATISTICAL ANALYSIS}

Student's $t$ test for unpaired data and linear regression analysis were performed on a Hewlett Packard calculator (HP-41C). The diagnostic value of individual parameters was assessed by Bayesian analysis $^{16-18}$ details of which are given in the appendix.

\section{Results}

CLINICAL FEATURES

Limb pain was present in 18 of $26(69 \%)$ subjects with osteomalacia and in three of $15(20 \%)$ subjects with osteoporosis. Back pain was present in all subjects with osteoporosis and in 12 of $26(46 \%)$ subjects with osteomalacia. Back pain only was present in three of $26(12 \%)$ subjects with osteomalacia. Five subjects (19\%) with osteomalacia did not give a history of bone pain. Proximal myopathy was a feature occurring only in osteomalacia in eight of $26(31 \%)$ subjects.

\section{SERUM CHEMISTRY}

Serum chemistry (serum calcium-phosphate product, alkaline phosphatase and $25(\mathrm{OH})$ vitamin D) was normal in the majority of patients with osteoporosis (nine of 15), while of the remaining six, four patients had a single abnormality and two patients had two abnormalities. One patient with osteomalacia had normal serum chemistry, four patients had a single abnormality, 10 patients had two abnormalities and 11 patients had three abnormalities (Table 2). Two of three osteoporotic patients with a low calciumphosphate product, and three of four osteomalacic subjects with a normal serum calcium-phosphate product had total serum calcium "corrected for" albumin. ${ }^{19}$ Despite "correction" of total calcium for albumin in these subjects, the calcium-phosphate product remained discordant.

\section{RADIOLOGY}

Pseudofractures normally associated with osteomalacia were present in six of $26(23 \%)$ patients with osteomalacia and in one of $15(7 \%)$ of subjects with osteoporosis. Collapsed vertebrae and decreased vertebral body density were by definition present in all subjects with osteoporosis, but also present in seven of $20(35 \%)$ and 16 of $20(80 \%)$ respectively of patients with osteomalacia.

\section{IN DEX}

Collating the results of the investigations in the proposed index gave osteomalacic patients a mean $( \pm \mathrm{SD}$ ) percentage score of $54.8 \pm 22.3 \%$ (range 8$92 \%$ ) and patients with osteoporosis $8.4 \pm 10.2 \%$ (range 0-30\%). Fig. 1 demonstrates the minimal degree of overlap between the two groups using the

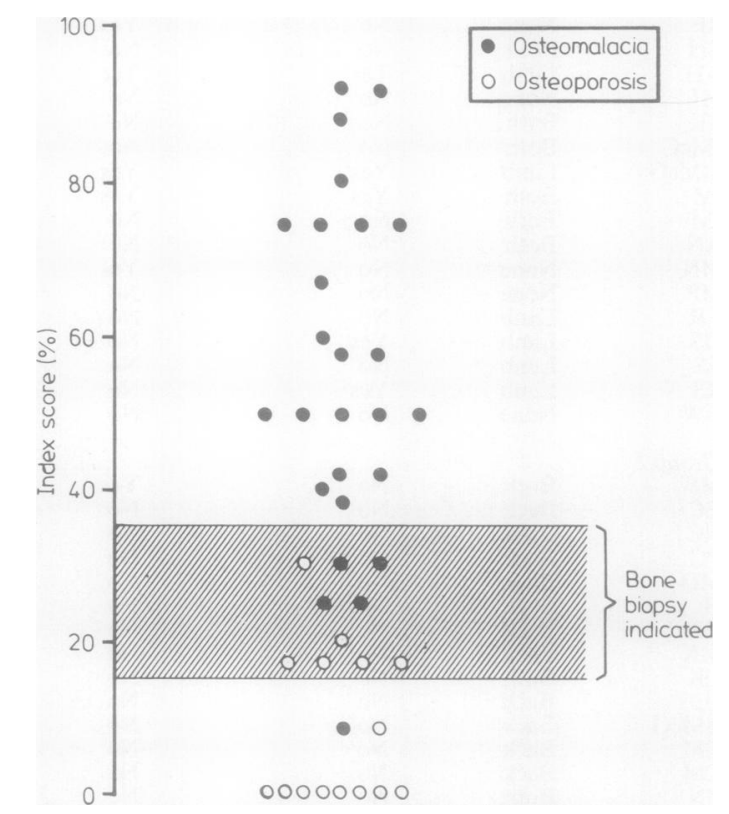

Fig. 1 Index scores in patients with osteomalacia and osteoporosis. 


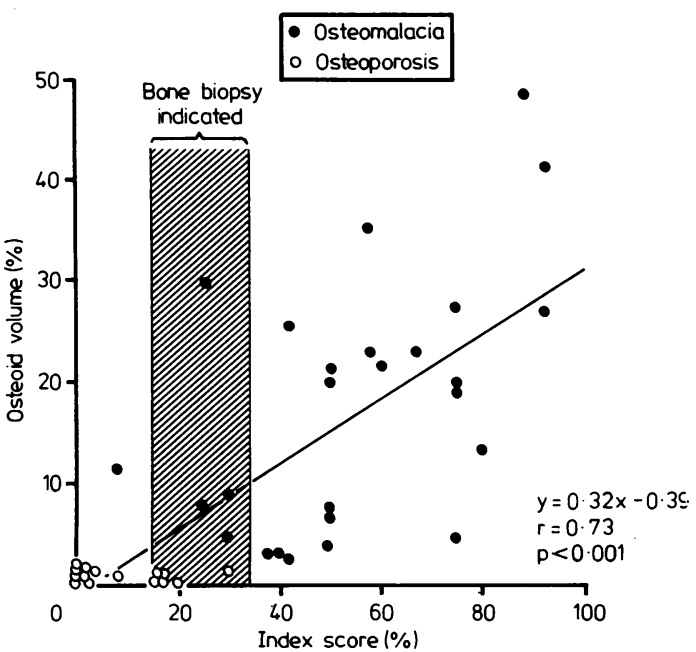

Fig. 2 Correlation of index score with osteoid volume in osteomalacia and osteoporosis.

Table 4 Correlation between osteoid volume and individual parameters

\begin{tabular}{lrl}
\hline Parameter & $\begin{array}{l}\text { Correlation } \\
\text { coefficient }\end{array}$ & p value \\
\hline Serum calcium-phosphate product & -0.51 & $<0.001$ \\
Serum alkaline phosphatase (log units $_{\text {) }}$ & 0.63 & $<0.001$ \\
Serum 25 (OH) vitamin D & -0.56 & $<0.001$ \\
Index & 0.73 & $<0.001$ \\
\hline
\end{tabular}

index $(t=7 \cdot 57, \mathrm{p}<0 \cdot 001)$. A bone biopsy is needed to make a definitive diagnosis for scores between $15 \%$ and $35 \%$. The quantitative histological assessment of osteoid volume which was used as a standard reference in the classification of the two groups was plotted versus the index score for the individual patients in each group and Fig. 2 shows the degree of correlation obtained $(r=0.73, p<0.001)$. The correlation coefficients of the osteoid volume with

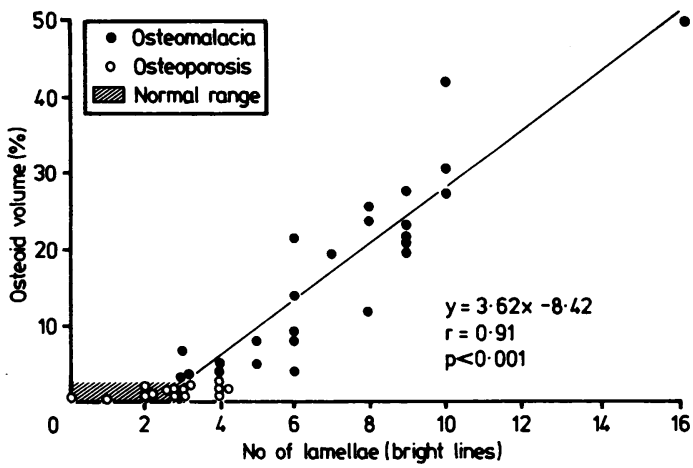

Fig. 3 Correlation of maximum number of lamellae with osteoid volume in osteomalacia and osteoporosis.

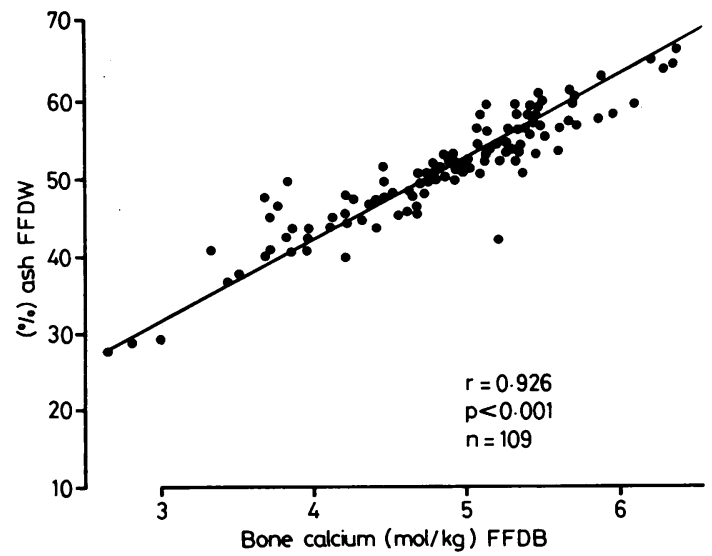

Fig. 4 Correlation of bone calcium with bone ash content.

individual indicants listed in the index are shown in Table 4. No single indicant approaches the degree of correlation between the osteoid volume and the index score. The index gives a higher risk ratio and a lower degree of misclassification than any single indicant (Table 5). Table 5 also lists the sensitivity,

Table 5 Ability of each parameter to predict the presence of osteomalacia (percentages)

\begin{tabular}{|c|c|c|c|c|c|c|c|}
\hline \multirow[t]{2}{*}{ Parameter } & \multirow{2}{*}{$\begin{array}{l}\text { Pretest } \\
\text { probability }\end{array}$} & \multirow[t]{2}{*}{ Sensitivity } & \multirow[t]{2}{*}{ Specificity } & \multicolumn{2}{|c|}{ Predictive values: } & \multirow{2}{*}{ Risk ratio } & \multirow{2}{*}{$\begin{array}{l}\text { Degree of } \\
\text { misclassification }\end{array}$} \\
\hline & & & & Positive & Negative & & \\
\hline $\begin{array}{l}\text { Limb pain } \\
\text { Back pain } \\
\text { Proximal myopathy } \\
\text { Serum calcium-phosphate product }<2.42 \\
\text { Serum alkaline phosphatase }>75 \mathrm{IU} / 1 \\
\text { Serum } 25(\mathrm{OH}) \text { vitamin } \mathrm{D}<5.0 \mathrm{nmol} / \\
\text { Pseudofractures } \\
\text { Bone ash content }<52 \% \\
\text { Maximum number of lamellae }>3 \\
\text { Index score }>20 \%\end{array}$ & $\begin{array}{l}63 \\
63 \\
63 \\
63 \\
61 \\
63 \\
63 \\
62 \\
63 \\
63\end{array}$ & $\begin{array}{l}69 \\
46 \\
31 \\
85 \\
91 \\
70 \\
23 \\
74 \\
88 \\
96\end{array}$ & $\begin{array}{r}80 \\
0 \\
100 \\
80 \\
67 \\
100 \\
93 \\
43 \\
73 \\
93\end{array}$ & $\begin{array}{r}86 \\
44 \\
100 \\
88 \\
81 \\
100 \\
86 \\
68 \\
85 \\
96\end{array}$ & $\begin{array}{r}60 \\
0 \\
45 \\
75 \\
83 \\
67 \\
41 \\
50 \\
79 \\
93\end{array}$ & $\begin{array}{r}2.1 \\
0.4 \\
1.8 \\
3.5 \\
4.8 \\
3.0 \\
1.5 \\
1.4 \\
4.0 \\
14.0\end{array}$ & $\begin{array}{r}27 \\
71 \\
44 \\
17 \\
18 \\
19 \\
51 \\
38 \\
17 \\
5\end{array}$ \\
\hline
\end{tabular}


specificity and predictive values of each parameter. Omission of serum $25(\mathrm{OH})$ vitamin $D$ results would reduce the discrimination between the index score for osteoporosis and osteomalacia-reducing the $t$ value from 7.57 to 5.89 and expanding the percentage range for biopsy (10 to $35 \%$ ) which increases the number of patients in this category from 10 to 15 . Omission of serum alkaline phosphatase results reduces the $t$ value from $7 \cdot 57$ to $6 \cdot 76$, and results in biopsy being indicated in only one additional case. Formal discriminant function analysis requires that all parameters be available in each patient. Alternatively different discriminant functions must be designed to accommodate the exclusion of parameters-that is, alkaline phosphatase in subjects with concomitant liver disease, or serum $25(\mathrm{OH})$ vitamin D levels in patients on parent vitamin D supplements. Therefore this simple index was preferred as obligatory omission of a parameter does not preclude the use of the index.

\section{HISTOLOGY}

Osteoid volume which was a factor used in the classification of osteoporotic and osteomalacic subjects, was by definition raised $(>2.4 \%)$ in osteomalacia and normal $(<2.4 \%)$ in osteoporosis. The maximum number of lamellae per osteoid seam was $>3$, in four of $15(27 \%)$ subjects with osteoporosis and in 23 of $26(88 \%)$ subjects with osteomalacia. There was a highly significant correlation ( $r=0.91$, Fig. 3) between the osteoid volume and the number of lamellae. Bone ash content was low $(<52 \%)$ in 17 of 23 osteomalacic patients, but lacked specificity as it was also low in eight of 14 osteoporotic patients. There was significant negative correlation $(\mathrm{r}=-0.33, \mathrm{p}<0.05)$ between bone ash content and osteoid volume. Bone calcium although measured was excluded from the index on the basis that $\%$ bone ash yielded largely the same information, and was easier to measure. In a large series with various disorders of calcium metabolism a high degree of correlation $(r=0.926, p<0.001)$ was seen between $\%$ bone ash and bone calcium (Fig. 4).

\section{Discussion}

The index, which represents the cumulative points scored for all the parameters assessed in each patient, discriminates with a minimum of overlap between the osteoporotic and osteomalacic groups (Fig. 1). A score above $35 \%$ would be diagnostic of osteomalacia. A score below $15 \%$ would exclude osteomalacia in all but one case, and if associated with collapsed vertebrae (or decreased bone density) would suggest a diagnosis of osteoporosis (or osteopenia). A score below $15 \%$ with a normal spinal $x$-ray should exclude both these forms of metabolic bone disease. A score between 15 and $35 \%$ would indicate that a bone biopsy is needed for definitive diagnosis. Partial validation of this index of metabolic bone disease lies in its close correlation with the osteoid volume in biopsy specimens, which allows the degree of demineralisation - that is, excess osteoid, to be predicted with some degree of confidence from the index score (Fig. 2).

In this retrospective study, nine patients with osteoporosis and 21 patients with osteomalacia could have their correct diagnosis predicted by use of the index. Ten patients would need a bone biopsy to $ㅇ ㅡ ㅇ$ make a definitive diagnosis. Complete validation of $\omega$ the index will depend on its application in a larger $\dot{\omega}$ prospective study. In its present form it is easy to i apply and suggests a new method of assessing the $\mathrm{C}$ diagnostic significance of the tests usually performed. $\frac{\mathrm{O}}{\mathrm{T}}$ If newer non-invasive procedures such as bone scanning $^{20}$ or photon beam absorptiometry ${ }^{21}$ could $\bar{z}$ give useful information when results of the index are equivocal (15 to $35 \%$ ), further reduction in the $工$ numbers of subjects needing bone biopsy may be $\overrightarrow{0}$ achieved.

The prevalence of osteomalacia and osteoporosis will vary with age and population studied. Is the index still useful as the disease prevalence changes? This question is answered by considering its positive and negative predictive values over a wide range of disease prevalences (Fig. 5). It is clear that even when the prevalence of disease is as low as $5 \%$, the index is still useful in a positive and negative predictive way.

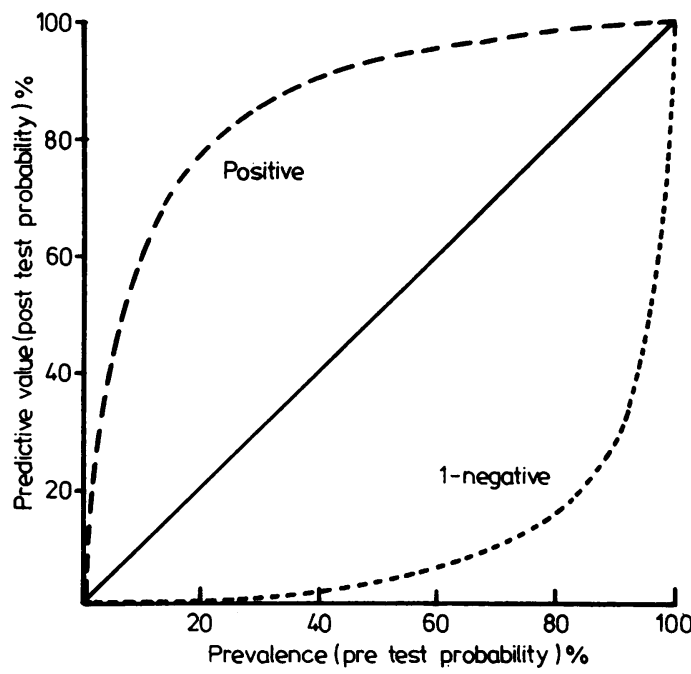

Fig. 5 Predictive values for index at different prevalences of osteomalacia. 
Hodkinson, ${ }^{22}{ }^{23}$ using discriminant function analysis, suggested a combination of biochemical results (calcium corrected for albumin, phosphate, alkaline phosphatase) as a diagnostic aid in osteomalacia. The discriminatory power of the combined results surpassed any individual parameter. Serum 25 hydroxy vitamin D levels were not available at that time. Our data support Hodkinson's observation that a combination of biochemical results is preferable to consideration of the individual results but in addition, the index suggested here incorporates some clinical and radiological features.

Significant vitamin $\mathrm{D}$ deficiency, as assessed by serum $25(\mathrm{OH})$ D levels, only occurred in subjects with osteomalacia. It should be stressed that a low or undetectable $25(\mathrm{OH})$ vitamin $\mathrm{D}$ level does not indicate that osteomalacia is present. ${ }^{24}{ }^{25}$ However, this form of bone disease rarely occurs in patients with normal 25 hydroxy vitamin levels in serum. ${ }^{26}$

Pseudofractures are usually considered to be diagnostic of osteomalacia, but they are uncommon. In this study they were noted infrequently in osteomalacic patients, and only occurred in the presence of a gross excess of osteoid-that is $>19 \%$. Pseudofractures have also been reported in the absence of osteomalacia, ${ }^{27}$ as was noted in one case in this study. Bilateral pubic rami (superior and inferior) pseudofractures were noted in a 58-year-old woman (MB) who did not have a history of significant trauma. All other indices of osteomalacia were normal (Tables 2 and 3 ).

Subjective assessment of bone radiodensity alone is not indicative of a bone disorder. However, it is valuable in indicating bone demineralisation as demonstrated by the studies of Goldsmith et al,$^{28}$ who assessed its precision and usefulness relative to bone mineral measurements. It is interesting that the "classical" radiological features of osteoporosis (collapsed vertebrae, decreased vertebral body density) frequently occurred in patients with osteomalacia. Frame ${ }^{1}$ states that vertebral compression is uncommon in osteomalacia unless osteoporosis is also present. While these subjects may have both osteoporosis and osteomalacia, it is important to detect the latter since it is the reversible component of their bone disease.

The presence of excess osteoid is currently the sine qua non to the diagnosis of osteomalacia. ${ }^{2}$ Defective mineralisation of bone predisposes to the accumulation of non-mineralised bone matrix-that is, osteoid. Toluidine blue staining or tetracycline labelling is necessary to detect mineralisation defects, ${ }^{2}$ but these procedures are not always performed. In this study the Tripp and MacKay technique was used to assess the quantity of osteoid, and thus determine the presence or absence of osteomalacia. While we are aware that this does not give a complete picture of bone status in osteomalacia it is a simple method within the competence of any laboratory. Quantitative assessment of osteoid, which is a tedious procedure, need not always be done. Analysis of osteoid seam thickness by counting the number of lamellae (bright lines) gives reliable information in this and previously reported studies. ${ }^{13}{ }^{14}$ Mineral content of bone tissue in biopsy samples as measured by bone ash determination was studied with regard to its correlation with osteoid volume, and with regard to its diagnostic value in osteomalacia. Data show significant but low correlation $(r=-0.33, p<0.05)$ between osteoid volume and \% bone ash. Morgan ${ }^{4}$ in a previous study comparing bone ash and amount of osteoid reported similar findings. Low specificity limits its diagnostic usefulness. Subjective assessment of the quantity of osteoid (by an experienced pathologist) agreed with the disease classification determined by quantitative assessment in 37 of 41 cases (Table 2). In the four discordant cases, subjective assessment indicated a mild excess of osteoid.

In summary, an index of metabolic bone disease is presented that is simple to apply, gives good separation between subjects with and without osteomalacia, and indicates when a bone biopsy is necessary. Based on the evidence from this study, bone biopsy is not necessary to confirm a diagnosis of osteomalacia in patients with scores above $35 \%$.

We would like to thank Leslie Daly (MSc), Lecturer in Medical Statistics, University College Dublin for his valuable help and advice with the statistics in this paper.

\section{Appendix}

\section{SYMBOLS}

$$
\begin{array}{ll}
\text { TP }=\text { True-positive } & \text { FP }=\text { False-positive } \\
\text { TN }=\text { True-negative } & \text { FN }=\text { False-negative } \\
\mathrm{p}=\text { probability } & t=\text { test } \\
/=\text { given that } & \mathrm{D}=\text { disease }
\end{array}
$$

\section{SENSITIVITY}

It is the probability of a positive result occurring in a patient with disease.

$$
\mathrm{p}^{\left(t^{+}\right) /\left(\mathrm{D}^{+}\right)}=\frac{\mathrm{TP}}{\mathrm{TP}+\mathrm{FN}}
$$

\section{SPECIFICITY}

It is the probability of a negative test result occurring in a patient without disease.

$$
\mathrm{p}^{\left(t^{-}\right) /\left(\mathrm{D}^{-}\right)}=\frac{\mathrm{TN}}{\mathrm{TN}+\mathrm{FP}}
$$


PRETEST PROBABILITY

It is the probability of disease in a patient to be tested (ie prevalence).

$$
\mathrm{p}^{\left(\mathrm{D}^{+}\right)}=\frac{\text { Number with disease }}{\text { Number tested }}=\frac{\mathrm{TP}+\mathrm{FN}}{\mathrm{TP}+\mathrm{FN}+\mathrm{TN}+\mathrm{FP}}
$$

\section{POST TEST PROBABILITY}

The probability that disease is present in a patient with a positive test result is the positive predictive value.

$\mathrm{p}^{\left(\mathrm{D}^{+}\right) /\left(t^{+}\right)}=\frac{\mathrm{TP}}{\mathrm{TP}+\mathrm{FP}}$

The probability that disease is absent in a patient with a negative test result is the negative predictive value. $\mathrm{p}^{\left(\mathrm{D}^{-}\right) /\left(t^{-}\right)}=\frac{\mathrm{TN}}{\mathrm{FN}+\mathrm{TN}}$

\section{RISK RATIO \\ $\frac{\mathrm{TP}}{\mathrm{TP}+\mathrm{FP}} / \frac{\mathrm{FN}}{\mathrm{TN}+\mathrm{FN}}=\frac{\text { Positive predictive value }}{1-\text { Negative predictive value }}$}

DEGREE OF MISCLASSIFICATION $\mathrm{FP}+\mathrm{FN}$

$\overline{\mathrm{TP}+\mathrm{FP}+\mathrm{TN}+\mathrm{FN}}$

\section{References}

${ }^{1}$ Frame B, Parfitt AM. Osteomalacia: Current concepts. Ann Intern Med 1978:89:966-82.

2 Teitelbaum SL. Pathological manifestations of osteomalacia and rickets. Clin Endocrinol Metab 1980;9:43-62.

${ }^{3}$ Thompson DL, Frame B. Involutional osteopenia: current concepts. Ann Intern Med 1976;85:789-803.

${ }^{4}$ Morgan DB, Stanley J, Fourman P. The mineral deficit in osteomalacic bone. Clin Sci 1968;35:337-45.

${ }^{5}$ Crooks J, Murray IPC, Wayne EJ. Statistical methods applied to the clinical diagnosis of thyrotoxicosis. Q J Med 1959;28:21134.

${ }^{6}$ Taussig LM, Kattwinker J, Friedwalk WT, diSant'Agnese PA. A new prognostic score and clinical evaluation system for cystic fibrosis. J Pediatr 1973;82:380-90.

${ }^{7}$ McKenna M, Freaney R, Keating D, Muldowney FP. The prevalence and management of vitamin $D$ deficiency in an acute geriatric unit. Irish Med J 1981;74:336-8.

${ }^{8}$ Ladenson JH, Lewis JW, Boyd JC. Failure of total calcium corrected for protein, albumin, and $\mathrm{pH}$ to correctly assess free calcium status. J Clin Endocrinol Metab 1978;46:986-93.

${ }^{9}$ Byers P, Smith R. Trephine for full-thickness iliac-crest biopsy. $\mathrm{Br}$ Med J 1967;i:682-3.
${ }^{10}$ Tripp EJ, MacKay EH. Silver staining of bone prior to decalcification for quantitative determination of osteoid in sections. Stain Technol 1972;47:129-36.

11 Towers RP. A simplified approach to metabolic bone disease. $J$ Clin Pathol 1974;27:929.

12 Garner A, Ball K. Quantitative observations on mineralised and unmineralised bone in chronic renal azotaemia and intestinal $\overline{\bar{C}}$ malabsorption syndrome. J Pathol Bacteriol 1966;91:545-61.

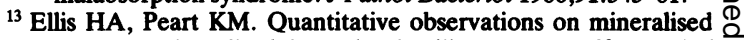
and non-mineralised bone in the iliac crest. J Clin Pathol 1972;25:277-86.

14 Woods CG, Morgan DB, Paterson CR, Grossman HH. Measure- $\vec{\circ}$ ment of osteoid in bone biopsy. J Pathol Bacteriol 1968;95:4417.

${ }^{15}$ Agna JW, Knowles HC, Alverson G. The mineral content of normal human bone. J Clin Invest 1958;37:1357-61.

${ }^{16} \mathrm{McNeil}$ BJ, Keeler E, Adelstein SJ. Primer on certain elements of ? medical decision making. N Engl J Med 1975;293:211-5. ஸे .

${ }^{17}$ Weiner DA, Ryan TJ, McCabe CH et al. Exercise stress testing. $N \underset{\omega}{\omega}$ Engl J Med 1979;301:230-5.

${ }^{18}$ Griner PF, Mayenski RJ, Mushlin AJ, Greenland P. Selection and interpretation of diagnostic tests and procedures: principles and applications. Ann Intern Med 1981;94:553-600.

${ }^{19}$ Payne RB, Little AJ, Williams RB, Milner JR. Interpretation of serum calcium in patients with abnormal serum proteins. $\mathrm{Br} Z$ Med J 1973;iv:643-6.

${ }^{20}$ Fogelman I, Bessent RG, Turner JG, Citrin DL, Boyle IT, Greig WR. The use of whole-body retention of Tc-99m diphosphonate in the diagnosis of metabolic bone disease. J Nucl Med 1978;19:270-5.

${ }^{21}$ Wilson CR. Bone mineral content of the femoral neck and spine versus the radius or ulna. J Bone Jt Surg 1977;59-A:665-9.

22 Hodkinson HM. Biochemical diagnosis of the elderly. London: Chapman and Hill, 1977:53-66.

${ }^{23}$ Hodkinson HM, Hodkinson I. A discriminant function for the biochemical diagnosis of osteomalacia in elderly subjects and its

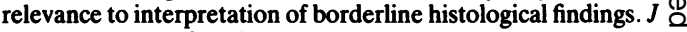
Clin Exp Gerontol 1980;2:123-31.

${ }^{24}$ Davie M, Lawson DEM, Jung RT. Low plasma 25-hydroxy vitamin D without osteomalacia. Lancet 1978;i:820.

${ }^{25}$ Hodkinson HM, Hodkinson I. Range for 25-hydroxyvitamin D in elderly subjects in whom osteomalacia has been excluded on histological and biochemical criteria. J Clin Exp Gerontol 1980;2:133-9.

${ }^{26}$ Preece MA, Tomlinson S, Ribot CA, et al. Studies of vitamin D deficiency in man. $Q J$ Med 1975;44:575-89.

${ }^{27}$ Perry HM, Fallon MD, Avioli LV, Teitelbaum SL. Pseudofractures in the absence of osteomalacia. In: Jee WSS, Parfitt $O$ AM, eds. Proceedings 3rd International Workshop on Bone Histomorphometry, Sun Valley. 1980:500.

${ }^{28}$ Goldsmith NF, Johnston OJ, Ury H, Vose G, Colbert C. Bone mineral estimation in normal and osteoporotic women. $J$ Bone $\frac{D}{O}$ Joint Surg 1971;53-A:83-100.

Requests for reprints to: Dr MJ McKenna, St Vincent's Hospital, Elm Park, Dublin 4, Eire. 